\begin{tabular}{|c|c|c|}
\hline \multirow[t]{2}{*}{7} & $\begin{array}{l}\text { International Journal of Current Research in } \\
\text { Biosciences and Plant Biology }\end{array}$ & \\
\hline & Volume $4 \bullet$ Number 6 (June-2017) • ISSN: 2349-8080 (Online) & \\
\hline PUBLISHERS & Journal homepage: www.ijcrbp.com & \\
\hline
\end{tabular}

\title{
Studies on Combining Ability for Yield and Yield Attributes in Groundnut (Arachis hypogaea L.)
}

\author{
K. John* and P. Raghava Reddy
}

Institute of Frontier Technology, Regional Agricultural Research Station, Tirupati-517 502, Andhra Pradesh, India

*Corresponding author.

\begin{tabular}{|c|c|}
\hline Abstract & Article Info \\
\hline $\begin{array}{l}\text { The specific combining ability variances was much greater than those of general } \\
\text { combining ability variances for all the characters except pod yield per plant, which } \\
\text { indicated the preponderance of non additive gene action. Among the lines, Prasuna had }\end{array}$ & $\begin{array}{l}\text { Accepted: } 30 \text { May } 2017 \\
\text { Available Online: O6 June } 2017\end{array}$ \\
\hline $\begin{array}{l}\text { shown significant positive } g c a \text { effect for kernel yield per plant. Narayani was found to be } \\
\text { good combiner for pod yield per plant as it showed significant and positive } g c a \text { effect. }\end{array}$ & Keywords \\
\hline $\begin{array}{l}\text { Among the testers, ICGV-91114 was found to be superior as it showed significant and } \\
\text { positive gca effect for number of mature pods per plant, shelling per cent, kernel yield per } \\
\text { plant and pod yield per plant. These parents could be used in breeding programme for } \\
\text { yield improvement through pedigree breeding. The best specific cross GreeshmaxDharani } \\
\text { was found to be desirable for kernel yield per plant. The cross NarayanixDharani had } \\
\text { showed significant sca effect for pod yield per plant. These crosses would be used for } \\
\text { further selection to obtain high yielding seggregants. }\end{array}$ & $\begin{array}{l}\text { General combining ability } \\
\text { Groundnut } \\
\text { Specific combining ability } \\
\text { Yield }\end{array}$ \\
\hline
\end{tabular}

\section{Introduction}

Groundnut is one of the leading oilseed crops of India and plays an important role in the economy of several countries. A choice of appropriate parents to be used in the hybridization programme is very essential to bring about the desired recombinants. The breeding strategy to be adopted for the improvement of a crop depends primarily on the nature of gene action involved in the expression of quantitative traits of economic importance. The information on the combining ability status of the genotypes will give an indication as to how well they combine with a given genotype to produce potential and productive populations and also on the nature of gene action involved. This helps the breeder to decide upon the choice of parents for hybridization and to isolate promising genotypes from the segregating populations. An investigation was taken up in groundnut involving a set of six lines and four testers were crossed in a line $x$ tester mating design, to study the general and specific combining ability and the gene action determining the yield and yield traits in this crop.

\section{Materials and methods}

Twenty four $F_{1}$ crosses were obtained by making crosses in $\mathrm{L} \times \mathrm{T}$ analysis. The lines viz., TAG-24, Prasuna, Rohini, Narayani, K-6 and Greeshma and testers viz., Dharani, TMV-2, TCGS-1416 and ICGV-91114. Twenty four $F_{1}$ s along with eight parents were sown in a 
Randomised Block Design (RBD) in three replications during kharif 2014. Each parent was sown in 3 rows of 3 $\mathrm{m}$ length while $\mathrm{F}_{1} \mathrm{~s}$ were raised in a single row of $3 \mathrm{~m}$ length. Ten random plants per replication were sampled in case of parents and $F_{1} s$ per replication were tagged at random for recording observations. Observations were recorded on ten random plants in parents and $F_{1}$ in each treatment per replication. The experiment was conducted in a red sandy loam soil with a neutral $\mathrm{pH}$, low in organic carbon. Recommended agronomic and plant protection measures were adopted for the conduct of experiment. Data were obtained for yield and yield attributes. The combining ability analysis was carried out according to Model I and Method II of Griffing (1956). The fixed effect model (Model I) was considered to be more appropriate in the present investigation since the study was restricted to the parents and direct crosses only.

\section{Results and discussion}

The magnitude of specific combining ability variances was much greater than those of general combining ability variances for all the characters except pod yield per plant, which indicated the preponderance of non additive gene action (Table 1).

Table 1. Analysis of variance for combining ability analysis for yield and yield attributes in groundnut.

\begin{tabular}{llllllllll}
\hline Source & d.f. & $\begin{array}{l}\text { Plant } \\
\text { height } \\
\text { (cm) }\end{array}$ & $\begin{array}{l}\text { No. of } \\
\text { primary } \\
\text { branches } \\
\text { per plant }\end{array}$ & $\begin{array}{l}\text { No. of } \\
\text { secondary } \\
\text { branches } \\
\text { per plant }\end{array}$ & $\begin{array}{l}\text { No. of } \\
\text { mature } \\
\text { pods per } \\
\text { plant }\end{array}$ & $\begin{array}{l}\text { Shelling } \\
\text { per cent }\end{array}$ & $\begin{array}{l}\text { Sound } \\
\text { mature } \\
\text { kernel } \\
\text { per cent }\end{array}$ & $\begin{array}{l}\text { Kernel } \\
\text { yield per } \\
\text { plant }(\mathbf{g})\end{array}$ & $\begin{array}{l}\text { Pod yield } \\
\text { per plant } \\
\text { (g) }\end{array}$ \\
\hline Replications & 2 & 26.04 & 0.00 & 0.00 & 1.68 & 1.35 & 2.63 & 0.11 & 326.88 \\
Crosses & 23 & 109.01 & 2.07 & 2.51 & 87.06 & 32.37 & 42.46 & 43.70 & 367.18 \\
Lines & 5 & 188.82 & 5.05 & 3.91 & 128.47 & 49.97 & 47.83 & 44.67 & 317.36 \\
Testers & 3 & 140.75 & 1.33 & 0.17 & 115.24 & 12.49 & 4.19 & 43.34 & 695.22 \\
L $\times$ T & 15 & 1140.95 & 18.25 & 37.71 & 1014.36 & 457.11 & 724.94 & 651.84 & 318.17 \\
Error & 46 & 18.43 & 0.00 & 0.00 & 0.61 & 0.50 & 1.00 & 0.30 & 316.91 \\
Var. (gca) & & 0.83 & 0.02 & 0.00 & 1.68 & 0.05 & -0.15 & 0.00 & 1.24 \\
Var. (sca) & & 19.21 & 0.41 & 0.84 & 87.06 & 9.99 & 15.78 & 14.39 & 0.42 \\
\hline
\end{tabular}

The general combining ability analysis effects and best combiners are presented in Tables 2 and 4 . The estimates of gca effects showed that among the lines, Rohini was found to be superior as it showed significant and positive gca effect for plant height. Greeshma was found to be superior as it showed significant and positive gca effect for number of primary branches per plant and Prasuna had shown significant positive gca effect for number of secondary branches per plant and kernel yield per plant. TAG-24 was found to be superior for number of mature pods per plant and shelling per cent as these lines showed significant and positive $\mathrm{gca}$ effect. K-6 recorded significant and positive gca effect for sound mature kernel per cent. Narayani was found to be good combiner for pod yield per plant as it showed significant and positive $g c a$ effect.

Among the testers, TCGS-1416 was found to be good combiner for plant height. ICGV-91114 was found to be superior as it showed significant and positive $g c a$ effect for number of secondary branches per plant, number of mature pods per plant, shelling per cent, kernel yield per plant and pod yield per plant. TMV-2 had shown significant positive gca effect for number of secondary branches per plant. Dharani was good combiner for sound mature kernel per cent and showed significant positive $g c a$ effect. Since, high gca effect is attributed to additive and additive $\mathrm{x}$ additive type of gene actions, these parents could be used in breeding programme for yield improvement through pedigree breeding.

The sca effects of the crosses and best crosses are presented in Tables 3 and 4. The cross Prasuna $\times$ TCGS1416 showed significant sca effect in the desirable direction for plant height, number of secondary branches per plant and number of mature pods per plant. The cross Greeshma $\times$ Dharani was found to be desirable for number of primary branches per plant and kernel yield per plant. The best specific combiner for shelling per cent was TAG- $25 \times$ Dharani. The cross Narayani $\times$ Dharani had showed significant $s c a$ effect for pod yield per plant. Earlier Nadaf et al. (1988) reported importance of additive gene action for pod yield per plant. Both additive and non-additive gene actions were reported for pod yield per plant by Sharma and Gupta (2008), Manivannan et al. (2008), Adamu et al. (2008), Jivani et al. (2009), Rekha et al. (2009), Savithramma et al. (2010), Mothilal and Ezhil (2010) and Ganesan et al. (2010). 
Table 2. General combining ability effects of parents for yield and yield attributes in groundnut.

\begin{tabular}{|c|c|c|c|c|c|c|c|c|}
\hline Traits & $\begin{array}{l}\text { Plant } \\
\text { height }(\mathrm{cm})\end{array}$ & $\begin{array}{l}\text { No. of } \\
\text { primary } \\
\text { branches } \\
\text { per plant }\end{array}$ & $\begin{array}{l}\text { No. of } \\
\text { secondary } \\
\text { branches per } \\
\text { plant }\end{array}$ & $\begin{array}{l}\text { No. of } \\
\text { mature } \\
\text { pods per } \\
\text { plant }\end{array}$ & $\begin{array}{l}\text { Shelling } \\
\text { per cent }\end{array}$ & $\begin{array}{l}\text { Sound } \\
\text { mature } \\
\text { kernel per } \\
\text { cent }\end{array}$ & $\begin{array}{l}\text { Kernel yield } \\
\text { per plant (g) }\end{array}$ & $\begin{array}{l}\text { Pod yield } \\
\text { per plant } \\
\text { (g) }\end{array}$ \\
\hline Lines & GCA & GCA & GCA & GCA & GCA & GCA & GCA & GCA \\
\hline TAG-24 & $-3.97 * *$ & $-0.25^{* *}$ & $0.25 * *$ & $4.34 * *$ & $2.01 * *$ & $1.83 * *$ & $1.5^{* *}$ & -0.72 \\
\hline Prasuna & $2.95^{*}$ & 0.00 & $0.74 * *$ & $3.35 * *$ & $-2.14 * *$ & $-1.33^{* *}$ & $2.16^{* *}$ & 1.22 \\
\hline Rohini & $-4.13 * *$ & $-0.50 * *$ & $-0.95 * *$ & $-1.79 * *$ & $1.33 * *$ & $1.17 * *$ & $-2.02 * *$ & -5.18 \\
\hline Narayani & $5.82 * *$ & $-0.50 * *$ & $0.23 * *$ & $-2.57 * *$ & $-2.49 * *$ & $-3.08 * *$ & $-1.44 * *$ & 8.19 \\
\hline K-6 & 0.89 & 0.00 & $-0.02 *$ & $-3.67 * *$ & $1.94 * *$ & $1.92 * *$ & $-1.76^{* * *}$ & -5.63 \\
\hline Greeshma & -1.56 & $1.24 * *$ & $-0.25^{* *}$ & 0.34 & $-0.64 * *$ & -0.5 & $1.55^{* *}$ & 2.12 \\
\hline $\begin{array}{l}\text { SE (gca for } \\
\text { lines) }\end{array}$ & 1.24 & 0.01 & 0.01 & 0.22 & 0.20 & 0.29 & 0.16 & 5.14 \\
\hline \multicolumn{9}{|l|}{ Testers } \\
\hline Dharani & 1.65 & 0.00 & $-0.09 * *$ & $-1.37 * *$ & $0.71 * *$ & $0.56^{*}$ & $-0.73 * *$ & -3.45 \\
\hline TMV-2 & -1.34 & $0.33 * *$ & $-0.08 * *$ & $-2.57 * *$ & 0.24 & -0.06 & $-0.85 * *$ & -3.76 \\
\hline TCGS-1416 & $-3.23 * *$ & 0.00 & $0.08 * *$ & $0.74 * *$ & 0.26 & 0.11 & $-0.75^{* *}$ & -2.04 \\
\hline ICGV-91114 & $2.92 * *$ & $-0.33^{* *}$ & $0.09 * *$ & $3.19 * *$ & $1.21 * *$ & $-0.61^{*}$ & $2.33 * *$ & $9.25^{*}$ \\
\hline $\begin{array}{l}\text { SE (gca for } \\
\text { testers) }\end{array}$ & 1.01 & 0.02 & 0.01 & 0.18 & 1.17 & 0.24 & 0.13 & 4.20 \\
\hline
\end{tabular}

* Significant at $5 \%$ level; ** Significant at $1 \%$ level.

Table 3. Specific combining ability effects of groundnut crosses for yield and yield attributes in groundnut.

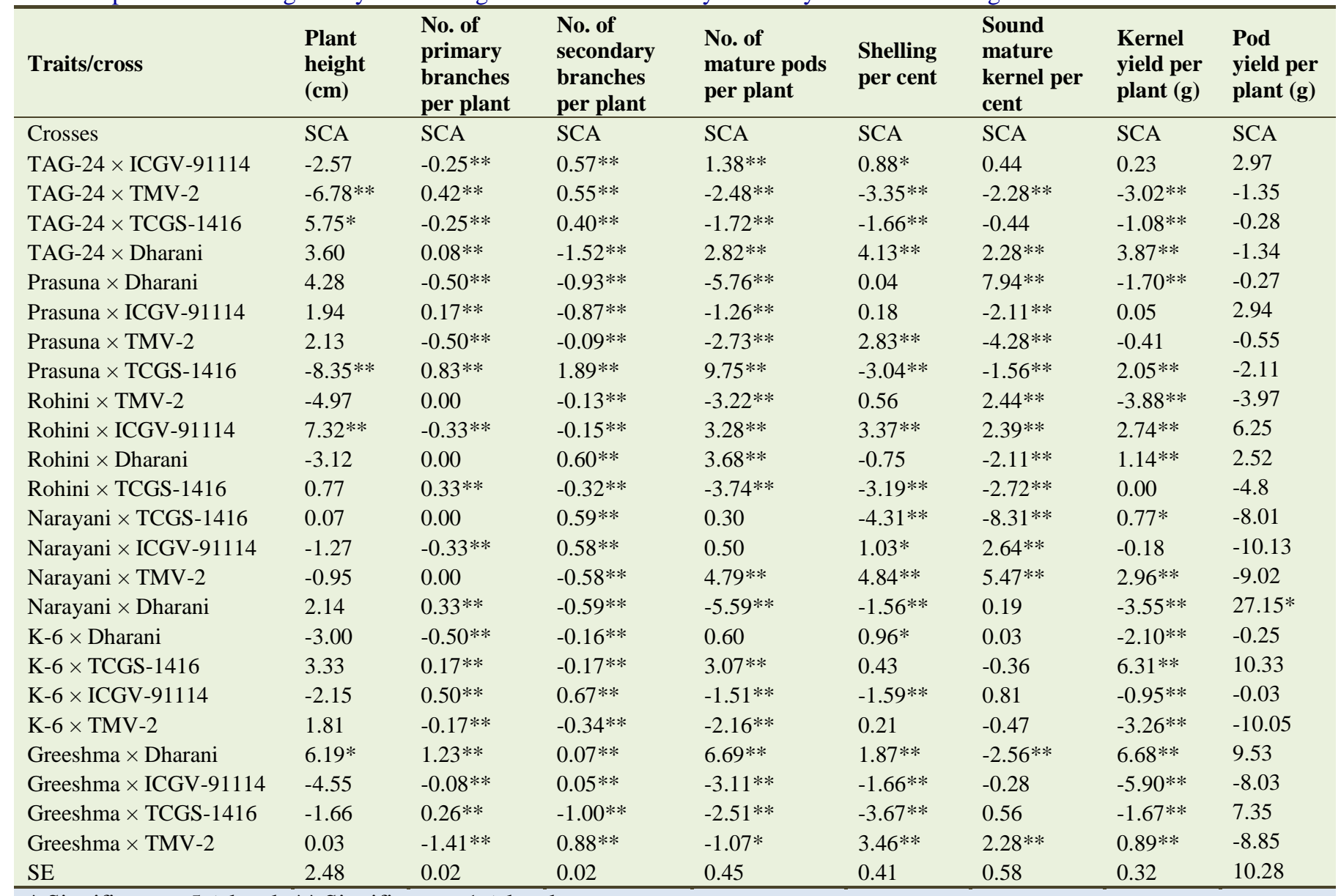

* Significant at 5\% level; ** Significant at $1 \%$ level 
Table 4. The best general and specific combiners for yield and yield attributes in groundnut.

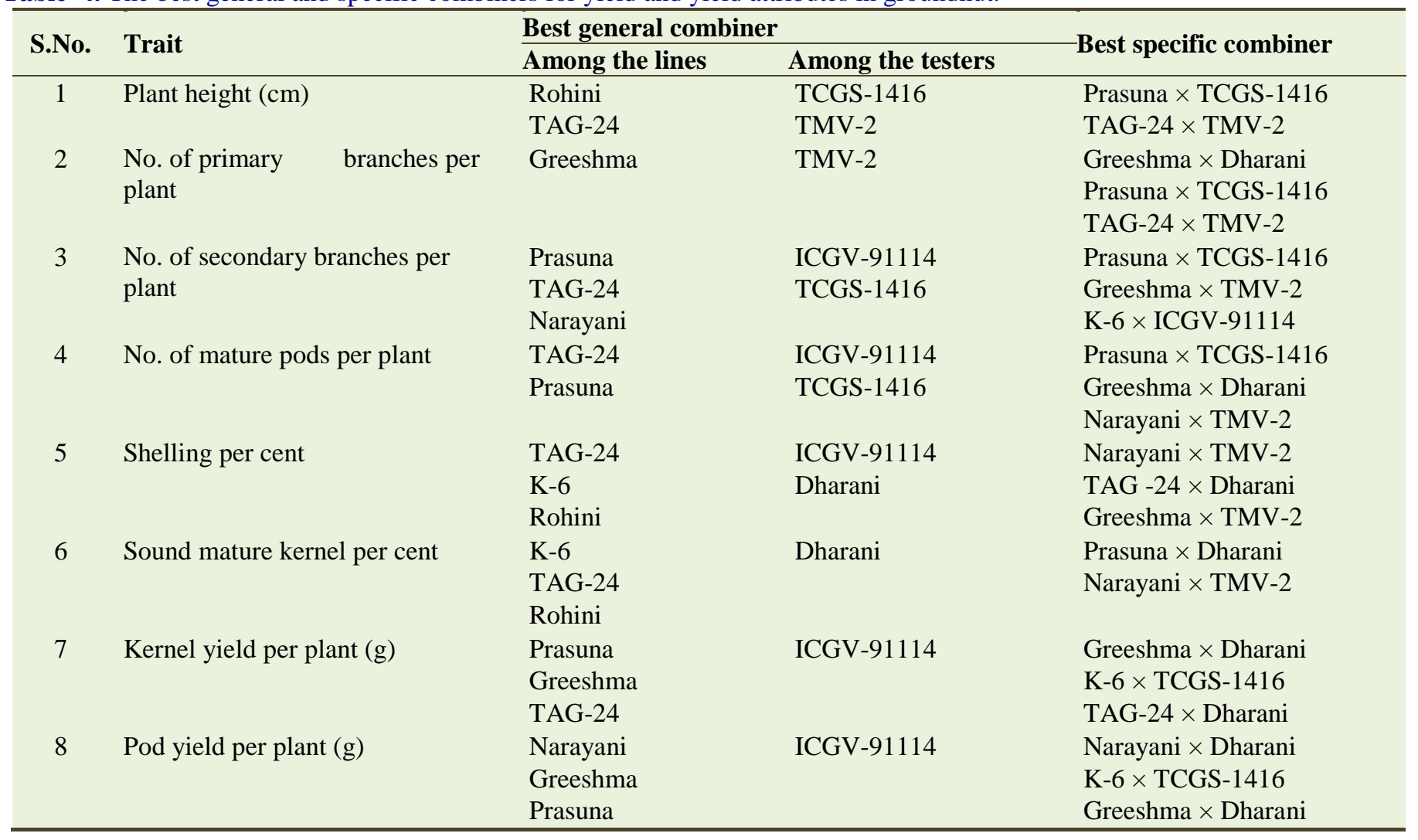

In conclusion, the parents among the lines, Rohini, Greeshma, Prasuna, TAG-24 and K-6 and among the testers TCGS-1416, ICGV-91114 and TMV-2 were considered as desirable parents and could be utilized in breeding programme. Among the crosses, Prasuna $\times$ TCGS-1416, Greeshma $\times$ Dharani, TAG-25 $\times$ Dharani and Narayani $\times$ Dharani were found to be the best specific combiners. Hence, these crosses would be used for further selection to obtain high yielding seggregants.

\section{Conflict of interest statement}

Authors declare that they have no conflict of interest.

\section{Acknowledgement}

This research was supported under the UGC Research award to the first author by the University Grants Commission (UGC), New Delhi is gratefully acknowledged.

\section{References}

Adamu, A.K., Olorunju, P.E., Ado, S.G., Alabi, S.O., 2008. General and specific combining ability for rosette resistance, early maturity and other agronomic traits in groundnut (Arachis hypogaea L.). Int. J. Pure Appl. Sci. 2(1), 33-41.

Ganesan, K. N., Paneerselvam, R., Manivannan, N., 2010. Identification of crosses and good combiners for developing new genotypes in groundnut (Arachis hypogaea L.). E-J. Plant Breed. 1(2), 167172.

Griffing, B., 1956. Concept of general and specific combining ability in relation to diallel crossing system. Austr. J. Biol. Sci. 9, 463-493.

Jivani, L. L., Khanpara, M. D., Kachhadia, V. H., Vacchani, J. H., 2009. Combining ability for pod yield and its components in groundnut (Arachis hypogaea L). Int. J. Agric. Sci. 5(1), 248-250.

Manivannan, N., Muralidharan, V., Mothilal, A., 2008. Combining ability analysis in groundnut (Arachis hypogaea L.). Madras Agric. J. 95(1-6), 14-17.

Mothilal, A., Ezhil, A., 2010. Combining ability analysis for yield and its components in groundnut (Arachis hypogaea L). E-J. Plant Breed. 1(2), 162-166.

Nadaf, H.L., Habib, A.F., Sresh, S., Patil, Syed, S., 1988. Heterosis and combining ability studies in groundnut. J. Oilseeds Res. 5, 7-15.

Rekha, D., Savithramma, D. L., Shankar, A. G., 
Marappa, N., 2009. Combining ability studies for growth and yield traits in groundnut (Arachis hypogaea L). Environ. Ecol. 27(1), 117-120.

Savithramma, D. L., Rekha, D., Sowmya, H. C., 2010. Combining ability studies for growth and related traits in groundnut (Arachis hypogaea L). E-J. Plant Breed. 1(4), 1010-1015.

Sharma, L. K., Gupta, S. C., 2008. Combining ability analysis in groundnut (Arachis hypogaea L). Res. Crops. 9(2), 375-379.

\section{How to cite this article:}

John, K., Raghava Reddy, P., 2017. Studies on combining ability for yield and yield attributes in groundnut (Arachis hypogaea L.). Int. J. Curr. Res. Biosci. Plant Biol. 4(6), 87-91. doi: https://doi.org/10.20546/ijcrbp.2017.406.010 